\title{
S.W. Polarographic Determination of Mercaptan Compounds and Free Sulfur in Petroleum Naphtha
}

\author{
By \\ Masayuki Kashiki and Kazuyoshi Ishida \\ (Research Center, Maruzen Oil Co., Ltd., Shimotsu-Cho, \\ Kaiso-Gun, Wakayama-Pref., Japan) \\ Received, July 1, 1964

\section{Introduction}

The application of a square-wave polarograph to the determination of small amounts of mercaptan compound and free sulfur in the mixed solution of methanol, pyridine and sodium acetate was studied. Mercaptan compounds and free sulfur in concentrations below $10 \mathrm{ppm}$ were easily determined in these mixed solvent with a saturated calomel electrode. The derivative wave heights were proportional to the concentrations as predicted by the theory of S.W. polarography (1), (2). The polarographic waves of free sulfur consisted of two waves; peak potential for the 1st wave was $-0.52 \mathrm{~V}$. vs. SGE. The peak potential of 2 nd wave was -0.72 V.vs. SCE. The peak potential of mercaptan compound ( $n$-propylmercaptan) was $-0.50 \mathrm{~V}$. vs. SCE.

The decomposition of mercaptan compounds in $0.4 \mathrm{M}$ sodium acetate at room temperature could be neglected within about an hour. The presence of disulfide had no influences on both the peak potential and the wave height. Hydrogen sulfide was removed by precipitation with cadmium sulfate. The limit of determination was governed by the solubility of naphtha in the base solution. The optimum region was in the concentrations from a few to 0.001 weight $\%$. The procedure was that the sample was dissolved in the mixed solution of 14 vol. $\%$ of pyridine, 86 vol. $\%$ of methanol, $0.4 \mathrm{M}$ sodium acetate and the solution was polarographed. The time required was only 30 minutes.

The method has the higher sensitivity than the conventional polarography, and was affected by irreversibly reduced materials, such as oxygen, on the measurement of mercaptan and free sulfur.

Attempts to increase the sensitivity of polarographic determination of these trace components were made in this paper.

\section{Apparatus and Reagents}

The Yanagimoto Model PA-102 recording polarograph and PM-1 multiplier attachment were used. The polarographic H-type cell with a saturated calomel electrode was used. A large capacitor (2000 $\mu \mathrm{F}$. electrolytic) was connected between the SCE and a platinium electrode to minimize resistance effects (See Fig. 1). ${ }^{(3)}$ The capillary constants in an open circuit $(h=61.0 \mathrm{~cm})$ were

$$
\begin{aligned}
t & =3.8 \text { seconds } \\
m & =2.721 \mathrm{mg} . \text { per second }
\end{aligned}
$$

All experimental measurements were made in an air-conditioned room with the temperature held constant to $25^{\circ} \pm 0.1^{\circ} \mathrm{C}$. Fifty-milliliter flasks were used to dilute the sample 


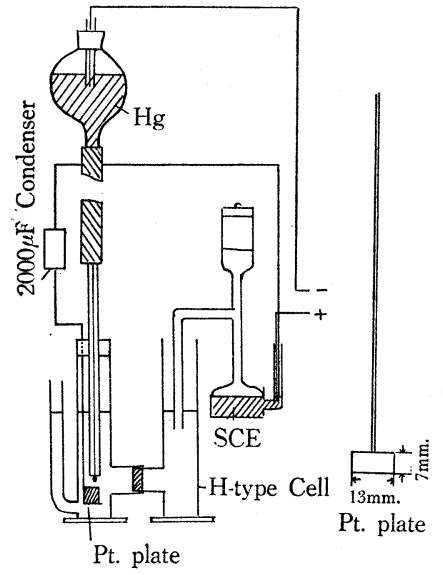

Fig. 1. H-cell with droppingmercury cathode.

with the mixed solution of electrolyte-solvent.

Wako's methanol, pyridine and sodium acetate were used. All of the reagents and chemicals used were of commercial extra pure grade or analytical reagent grade, and their purities were examined beforehand by polarography. Powdered monoclinic sulfur (free sulfur) of better than $99.9 \%$ purity was used for the preparation of standard solutions. The mixed solution of electrolyte-solvent was prepared by mixing 86 vol. \% of methanol, 14 vol. $\%$ of pyridine and $0.4 M$ sodium acetate.

A standard solution of known sulfur content was prepared by dissolving weighed amounts of the monoclinic sulfur in the solvent. The monoclinic form of sulfur was used because it was more soluble than other forms of sulfur, and also because the monoclinic form was used in doctor sweetening processes for gasolines.

\section{Experimental}

Because the method was to be applied mainly to petroleum samples, one of the major problems was to find a satisfactory solvent for the gasoline, sulfur, mercaptan and a supporting electrolyte. At first, the mixtures of pyridine, benzene, methanol and sodium acetate in various proportion were tried, but were found unsatisfactory mainly because gasoline would not blend enough with the mixed of electrolyte-solvent to permit an accurate determination of sulfur in the concentration range of 1 to $3 \mathrm{ppm}$ in the gasoline; at least that $10 \mathrm{ml}$. of the gasoline sample blends in $50 \mathrm{ml}$. was necessary for the most accurate work in this concentration range. Mixtures of various amounts of the low molecular weight alcohol with pyridine and sodium acetate were investigated as electrolytesolvent, and the most suitable combination found for mixing with gasoline was the mixture of methanol, pyridine and sodium acetate. The methanol serves as a solvent for gasoline; the pyridine serves as a solvent for free sulfur and mercaptan compounds.

\section{Polarogram of mercaptan compound and free sulfur}

(1) Mercaptan compound.

Mercaptan compounds were used ethyl-, n,t-propyl-, n,i,t-butyl-, n,i-amyl-, n,t-octyl-, lauryl, phenyl-, benzylmercaptan, and so on. Their purity was examined beforehand polarographically. Peak potential of their compounds covered -0.48 to $-0.55 \mathrm{~V}$. vs. SGE. S.W. polarogram of $20 \mathrm{ppm} n$-propyl mercaptan in the solution of $14 \mathrm{vol}$. $\%$ of pyridine, 86 vol. \% of methanol and $0.4 M$ sodium acetate is given in Fig. 2.

(2) Free sulfur.

The polarographic wave of free sulfur consisted of two waves; peak potential for the 1st wave was $-0.52 \mathrm{~V}$.vs. SCE. The peak potential of the 2 nd wave was $-0.72 \mathrm{~V}$. vs. SGE (See Fig. 2).

The lst wave of free sulfur and wave of mercaptan showed the same peak potential. Therefore, when free sulfur exists with mercaptan compound, the true wave height of mercaptan is obtained by deducting that of the lst wave of free sulfur from the total wave height. 


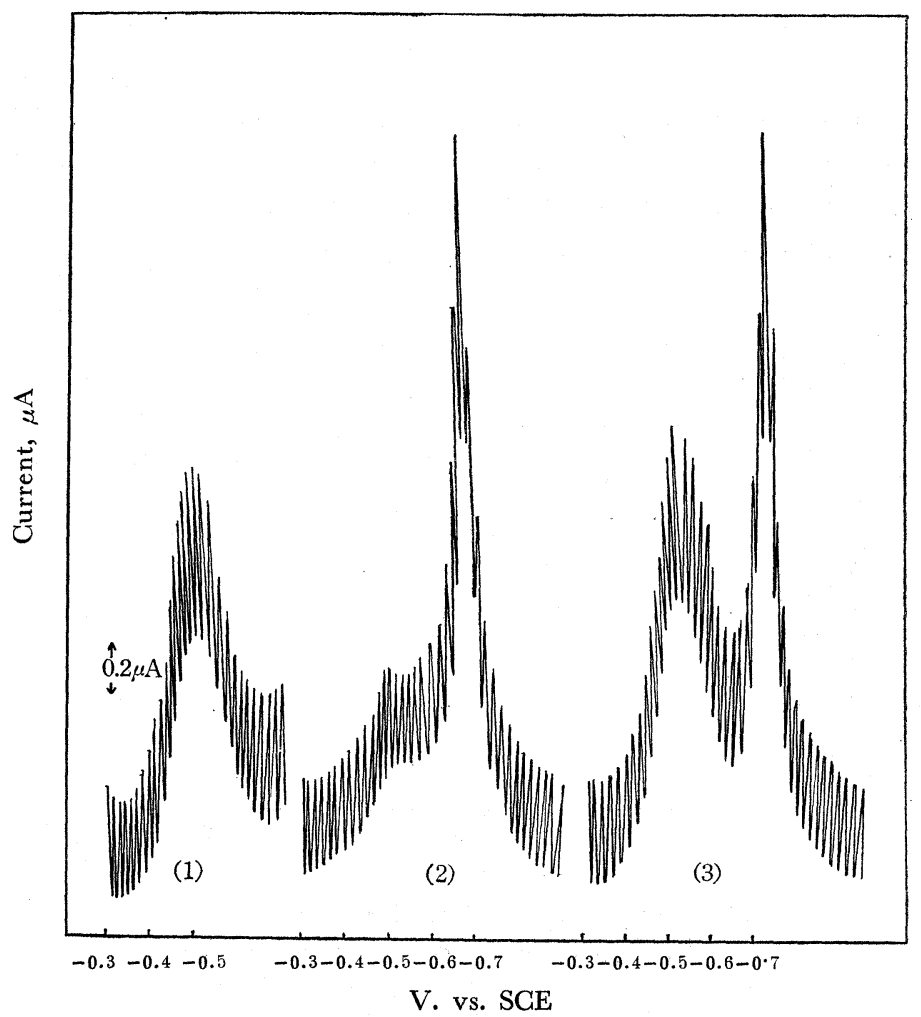

Fig. 2. Polarographic wave of mercaptan and free sulfur in methanol, pyridine and sodium acetate.

(1) 20 ppm. $n$-Propyl mercaptan, (2) $4 \mathrm{ppm}$. Free sulfur, (3) $(1)+(2)$, Initial Volt. $-0.3 \mathrm{~V}$. vs. SCE.

Parallel Capacitance : $50 \mu \mathrm{F}$. Recorder Sens. : $0.02 \mu \mathrm{A} /$ mm. Amplifier Sens. : 1/200, Gate : 1-7, S.W. Volt. Adjust : 20, Time constant : 81 .

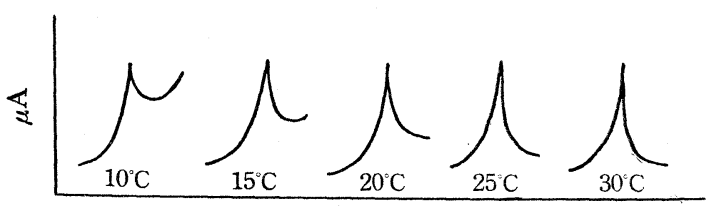

V. vs. SCE

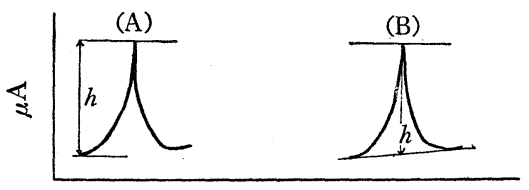

V. vs. SCE

Fig. 3. Effect of temperature on the polarogram of mercaptan.

Sample : $20 \mathrm{ppm}$. $n$-Propyl mercaptan. Initial Volt. $-0.3 \mathrm{~V}$. vs. SGE.

Parallel Capacitance : $50 \mu \mathrm{F}$. Gate : 1-7, S.W. Volt. Adjust : 20, Time Constant : 81 .

\section{The Effect of dissolved oxygen}

The wave of dissolved oxygen is overlapped by the wave of free sulfur and mercaptan in the mixed solution of 14 vol. \% of pyridine, 86 vol. \% of methanol, $0.4 M$ sodium acetate on S.W. polarogeams. Therefore, it is necessary for the determination of free sulfur and mercaptan to remove the dissolved oxygen by passing nitrogen for 30 min.

\section{The Effect of temperature}

(1) Mercaptan compound.

At low temperature $\left(10^{\circ} \mathrm{C}\right)$ the asymmetrical form of the S.W. ad- 
sorption wave is observed, but the wave form is being practically symmetrical as the temperature is raised (See Fig. 3). In the case of drawing method A, the plot of wave height against temperature shows no change, but in the case of drawing method B, it yields a straight line as shown in Fig. 4. It is seen in Fig. 4 that the wave height at any temperature is almost independent of the direction in which the temperature is changed. The temperature coefficient is about $19.6 \%$ per degree in the neighbourhood of $25^{\circ} \mathrm{C}$.

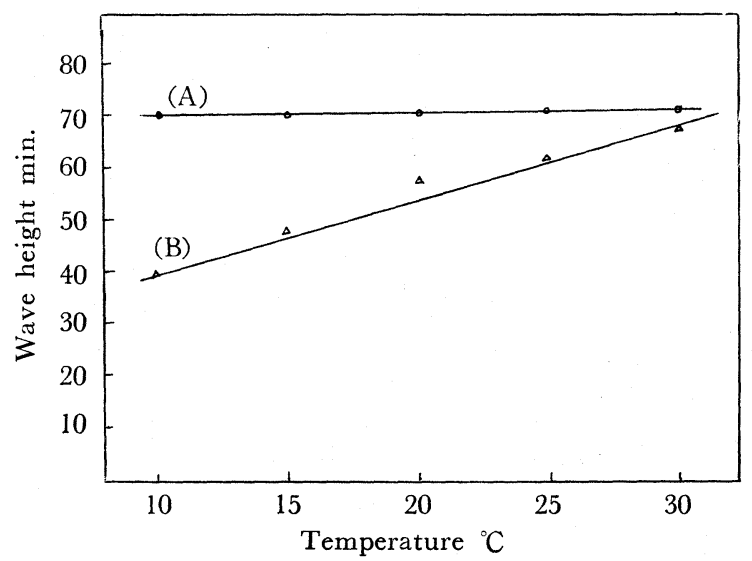

Fig. 4. Effect of Temperature (Mercaptan).

Parallel Capacitance : $50 \mu \mathrm{F}$. Recorder Sens. : $0.02 \mu \mathrm{A} / \mathrm{mm}$. Amplifier Sens. : 1/100, Gate : 1-7, S.W. Volt. Adjust : 20, Time Constant : 81, Sample : $20 \mathrm{ppm} n$-Propyl mercaptan

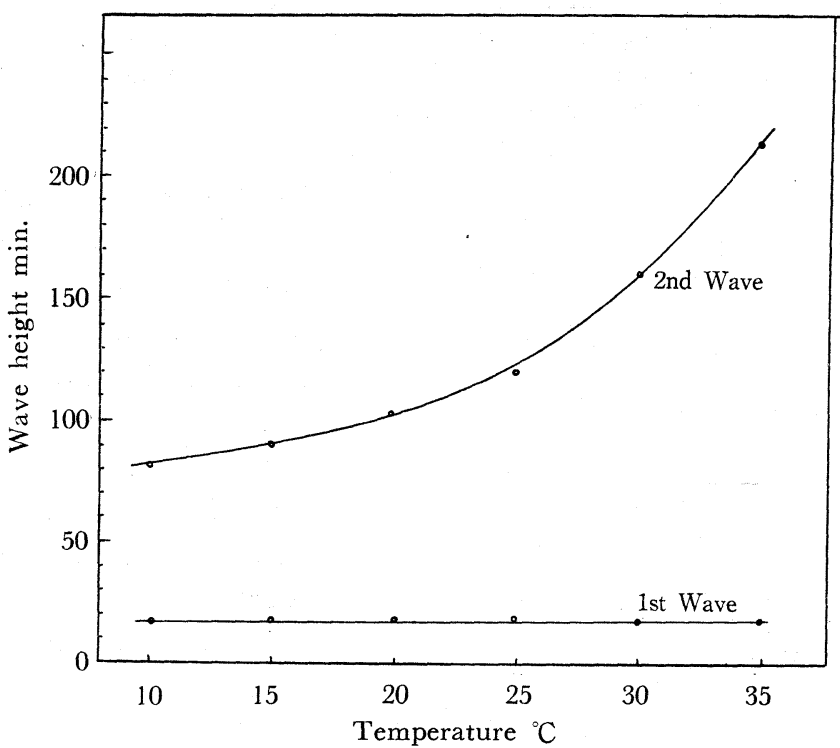

Fig. 5. Effect of Temperature (Free Sulfur)

Parallel Capacitance : $50 \mu \mathrm{F}$. Recorder Sens. : 0.04 $\mu \mathrm{A} / \mathrm{mm}$. Amplifier Sens. : 1/100, Gate : 1-7, S. W. Volt. Adjust : 20, Time Constant : 81 . 


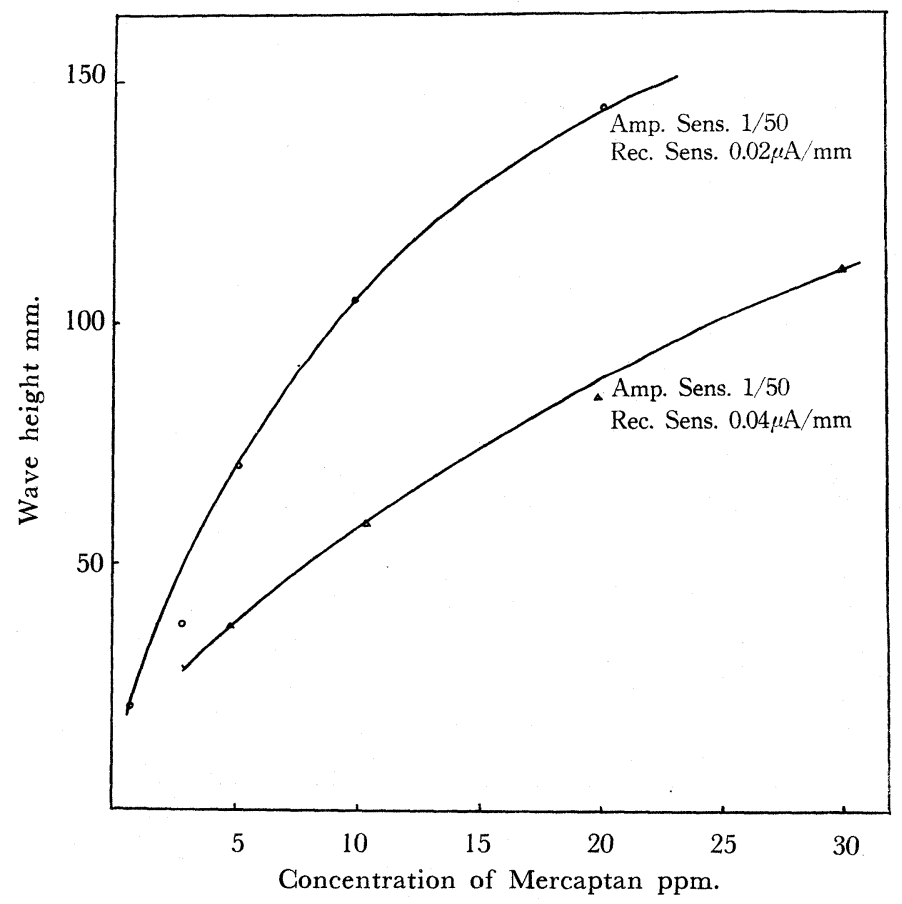

Fig. 6. Calibration curve of Mercaptan.

Parallel Capacitance : $50 \mu \mathrm{F}$. Gate : 1-7, S.W. Volt. Adjust : 20, Time Constant : 81 .

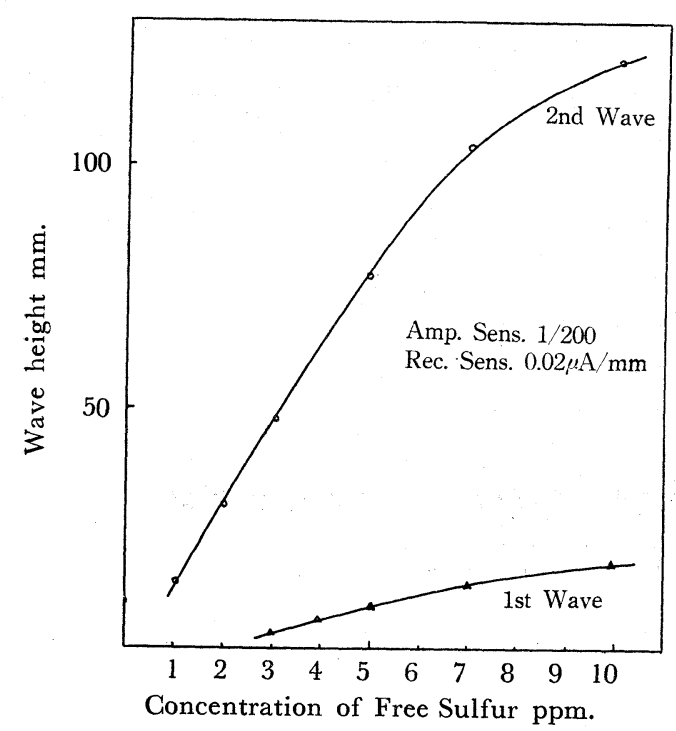

Fig. 7. Galibration curve of Free sulfur

Parallel Capacitance : $50 \mu \mathrm{F}$. Gate : 1-7 S.W. Volt. Adjust : 20, Time Constant : 81 .
(2) Free sulfur.

The polarographic wave of free sulfur consisted of two waves; the wave height for the lst wave was not affected by temperature, but the 2nd wave increases as the temperature is raised. A plot of wave height against temperature yields a curved line as shown in Fig. 5.

\section{Calibration curve}

(1) Mercaptan compound.

A known amount of the standard solution of mercaptan (n-propyl mercap$\tan )$ was added to the mixture of $14 \mathrm{vol}$. $\%$ of pyridine and $86 \mathrm{vol} . \%$ of methanol in a $50 \mathrm{ml}$. volumetric flask. An aliquot of the solution was taken in a cell and polarographed after deaeration. A calibration curve obtained by these procedures is shown in Fig. 6 . The poor linearity of calibration curve may be due to the nonlinearity of rectifier equipped in the instrument. The detectable limit of concentration of mercaptan compound was about $1 \mathrm{ppm}$. 
(2) Free sulfur.

The procedures of those experiments are the same as those in case of the mercaptan compound (See Fig. 7). The detectable limit of concentration of free sulfur was about 1 ppm.

\section{Conclusion}

In case of mercaptan the applied potential of $-0.52 \mathrm{~V}$. vs. SCE was used to measure the wave height. The results are shown in Table 1. It was observed that a well-defined wave was obtained only when the concentration of mercaptan was higher than $1 \mathrm{ppm}$ and that the wave was rather drawn out, extending from about -0.25 to $-1.0 \mathrm{~V}$. vs. SCE. A typical polarogram is shown in Fig. 2.

In case of free sulfur, the applied potential at $-0.72 \mathrm{~V}$. vs. SCE was used to measure the wave height.

Table 1

\begin{tabular}{c|c|c|c}
\hline Mercaptan (n-Propylmercaptan) & \multicolumn{2}{|c}{ Free Sulfur } \\
\hline $\begin{array}{c}\text { Concentration } \\
(\mathrm{ppm})\end{array}$ & $\begin{array}{c}\text { Percentage error } \\
(\%)\end{array}$ & $\begin{array}{c}\text { Concentration } \\
(\mathrm{ppm})\end{array}$ & $\begin{array}{c}\text { Percentage error } \\
(\%)\end{array}$ \\
\hline 20 & 7.0 & 10 & 1.2 \\
5 & 9.6 & 6 & 3.0 \\
1 & 10.3 & 1 & 4.0 \\
\hline
\end{tabular}

\section{Acknowledgements}

The authers wish to express their grateful thanks to Dr. Reiji Takahashi of Ritsumeikan University, and Mr. Tsunehide Kozuma, General manager of Maruzen Oil Co., Ltd. Research Center, for their encouragement throughout the work.

\section{References}

1) T. Kambara, Rev. of polarography, 9, 149 (1953).

2) B. Breyer and H.H. Bauer, Rev. of polarography, 8, 155 (1960).

3) H.H. Bauer, P.J. Elving, Anal. Chem. 30, 334 (1958).

\section{ク形波ポーラログラフ法による石油留分中の徴量メルカプタン 化合物执よび遊離イオウの同時定量 \\ 梏 木正行, 石田和義 \\ （丸善石油株式会社中央研究所）}

本分析法はク形波ポーラログラフ法によりナフサ留 分中の極微量メルカプタンおよび遊離イオウを同時定 量するととを目的とする．メルカプタンのポーラログ ラフ法による定量法は1958年のハンブルスキム法によ る定性的な検討以外，今までのととろほとんど行なわ
れていない. また現在の ASTM 法, その他の方法で は，とうていてのような物質の極微量 (数 $\mathrm{ppm}$ ) 分析 は不可能である，一方，石油留分中の遊離イオウの定 量法については，1950年に Hall が，ガソリン留分に ポーラログラフ法を適用して以来，現在までに数種の 
改良法が発表されている。

（1）装置：楖本製，交直両用ポーラログラフ PA102 型および高感度装置 PM 1 型を使用した。電解セルに は Fig. 1 亿示すどとくH型セルに $2000 \mu \mathrm{F}$ コンデン サーを接続し, 液絡部の抵抗を出来るだけ少さくして 害験を行なった。

（2）基礎液 : 最適条件としてピリジン,メタノール， 酶酸ナトリウムの混合溶液を得た。そてで試料の溶解 度, 誘電率, その他種々条件を考慮して, その㓶合を 検討した結果，ピリジン $14 \mathrm{vol} \%$ ，メタノール $86 \mathrm{vol}$ $\%, 0.4 M$ 酶酸ナトリウムが最適と認めた。

(3) ポーラログラム :メルカプタンについては十数 種類の化合物について検討した結果，本分析法の基整 液によると，頂点電位は一 $0.48 〜-0.55 \mathrm{~V}$. vs. SCEを 示すととがわかった，その一例として，20 ppm.のnPropyl mercaptan が本基礎液中であたえるポーラロ グラムを Fig. 2 に示す。遊離イオウは. 二段波を示 し，第 1 波は-0.52V，第 2 波は-0.72V. vs. SCEに 頂点電位を示す。しかるに，遊離イオウの第 1 波とメ ルカプタン化合物の波が重なってくる，故淀量時に おいて，遊離イオウが共存している場合には，遊離イ オウの第 2 波の波高汃引検量線により第 1 波の波高を 求め,メルカプタンの真の波高を求め㸚ばならない。

（4）温度の影響 : メルカプタン化合物については。
Fig. 3 亿示す如く, 温度変化によって，ポーラログラ ムは変化する，乙の現象は滴下水銀電極上での吸着現 象尤るのではないかと考光られる。波高は作四の 仕方によって異なるが，Fig. 3 の(A) 法によると波高 に変化なく，(B) 法によ玌ば温度に比例して波高は高 くなる。. (Fig. 4 参照) 乙の場合の温度係数は 19.6\% /degree であった。 また遊離イオウについて，10〜35 ${ }^{\circ} \mathrm{C}$ の範囲内で検討した結果，Fig. 5 亿示すでとく，第 1 波は温度の影響を受けないが, 第 2 波は温度上昇と ともに波高は增加する。

（5）共存物質の影響 : ナフサ留分中で遊離イオウと メルカプタン以外のイオウ化合物として一応沸点範囲 から考光て， $\mathrm{H}_{2} \mathrm{~S}$, Disulfide などが考光られる。乙の うち $\mathrm{H}_{2} \mathrm{~S}$ は $-0.67 \mathrm{~V}$. vs. SCE にポーラログラムを 示し,遊離イオウのポーラログラムに影響をおよぼす。 したがって， $\mathrm{H}_{2} \mathrm{~S}$ は硫酸カドミウム処理により除去す る. 次に Dsiulfide であるが，てれは本条件において ポーラログラムを示さない.

以上の各条件により，分析した結果，分析精度は Table 1 亿示したとおりとなり，定量下限は，おのお の $1 \mathrm{ppm}$ で，ての時の相対誤差はメルカプタンにつ いては $10.3 \%$ ，遊離イオウは $4.0 \%$ となる。

(日本化学会，第17年会にて発表) 